\title{
Fostering political participation among students of Pesantren through new media in Madura
}

\author{
Ahmad Cholil ${ }^{1 *}$, Hasmah Zanuddin ${ }^{2}$ \\ ${ }^{I}$ Department of Media Study, Faculty of Arts and Social Sciences, University of Malaya, Kuala Lumpur, Malaysia. \\ ${ }^{1}$ Lecturer in the Department of Communication Sciences, FISIB, University of Trunojoyo Madura. \\ ${ }^{2}$ Department of Media Studies, Faculty of Arts and Social Sciences, University of Malaya, Kuala Lumpur, Malaysia. \\ *Corresponding author E-mail: cak.cholil.utm @gmail.com
}

\begin{abstract}
There are 911 of Islamic boarding schools in Madura. However, the students do not have easy access to the media via the Internet as expected. This is particularly due to some restrictions imposed by the schools on them in accessing the Internet. This resulted in the study of communication action between students of Islamic boarding schools and the new internet media; that is, how the schools and students can absorb the use of new media among students and how they play roles in political participation through new internet media. The present study employs a qualitative approach using ethnographic observations. The study uses Rogers' (1986) theory on the diffusion of innovation organizations and individuals, Roth's (1980) theory on political participation, and Wilson's (1980) theory on the pyramid of political participation. Based on diffusion of organizational innovation, it was found that the Banyuanyar Islamic boarding schools accept the existence of the Internet, but they experience lack of computer equipment (hardware), application program (software), as well as lack of experts and skills to use the facilities. As for the communication action, the use of the Internet gains wide acceptance. Most of the students even have basic knowledge to use the Internet before they enter school. The existence of media facilities may lead to the breach of rules by the students with regard to the policies of pesantren. Some efforts are needed to identify ethical violations in communication actions undertaken by the students in the use of the Internet. On the one hand, the identification of the Internet provides freedom space, but on the other, the pesantren does not have virtual security officers to deal with digital violations that may be committed by the students. The early identification of an effort is necessary to anticipate the adoption of innovations and to make boarding school students mediaintelligent. In term of the tendency of political participation, the students of pesantren Banyuanyar are participative in political activities. The policy made by the pesantren leaders plays a pivotal role in political participation. The education on political participation among students of pesantren through new media is reflected in the flow of information that is accessible everywhere, particularly electronic media, which has contributed significantly to developing the mindset of the people, especially among the students of pesantren.
\end{abstract}

Keywords: Diffusion of innovation; internet; pesantren; participation; Politic

\section{Introduction}

Islamic boarding schools, commonly known as pesantren, have a variety of styles and models of education systems. The hallmark of their existence is particularly supported by a system in which there is a group of religious students, known as santri, who settle in the institution and prominent figures known as kiai as the central point of reference for existing policies.

Based on the development number of pesantren boarding schools in Indonesia in 2008/2009, there are 24,206 boarding schools registered in the Planning and Data of Secretary General of Islamic Education, Ministry of Religion Affairs of Indonesia (1). There are 5,025 pesantren in East Java, 911 of which are located in Madura. Specifically, 170 pesantren are located in Bangkalan, 274 in Sampang, 230 in Pamekasan and 237 in Sumenep. This data is only on boarding schools that have been registered with the Department of Government through Depag RI. It means that the actual number of boarding schools that exist can be more than the ones that are recorded here. The unrecorded data are especially related to pesantren that still maintain the traditionality or the purely traditional boarding schools, which "reluctantly" register themselves to the Ministry of Religion Affairs (Depag). This is probably because their education systems do not apply formal education as defined by the Ministry of Religion Affairs (Depag) and Ministry of National Education (Depdiknas).

Nevertheless, pesantren especially in Madura has an important role in Madurese political map, which is related to the election of regional head (Pilkada) and related to general election (Pemilu). Because pesantren have massive pockets of people, both inside and outside the pesantren, and the elite of pesantren also have very strong bargaining power in politics and policy in the local government.

It is very common for pesantren and politics to be wrestling with each other and to have heated discussions on very interesting political issues. This is due to the fact that there are many active voters in boarding schools who are also considered to have an interest in politics. The development of new media has a role to play in constructing the political process. Students have freedom in expressing, behaving and acting even in the corridor of norms and rules of boarding school. New construction will be established on how santri can participate in politics on the Internet, and how they should participate in it smartly and politely. In this digital age, new media have important roles in constructing the existing political process; one of the new media that becomes the mainstay in constructing the process is the Internet. 
The Internet as a form of new media communication technology has spread in different ways, depending on the values contained in the communication technology itself and the cultural background of the recipient community of innovation. This process of the dissemination of new findings in a community or society is called innovation diffusion. According to Rogers and Shoemaker(2), the diffusion of innovation is the role of communication in transforming society through the spread of ideas and new things continuously beyond the boundaries of place, time, and field.

Internet technological advances are seen in the global number of Internet users of 2.4 billion people, with a growth rate of 8 percent, driven in developing countries. This number of users shows a population penetration ratio of 23 percent of the total population(3). Also visible on the development of new media in the field of internet, Indonesia has experienced a significant development. The leap of development in the broadcasting world also contributed to the growth of information and communication technology. According to the Ministry of Communication and Information (Kominfo), internet users in a short time get a great growth; it gains 45 million. A similar view is expressed by Yungfu (4) that mobile internet users in Indonesia are growing rapidly. Indonesia is ranked fifth as internet users and ranked fourth as mobile internet users in Asia. The ranking of countries based on Internet usage has also been published by the International Telecommunications Union website, Geneva(5), based on "Calculated using penetration rate and population data from" and "Percentage of Individuals using the Internet" data, showing that the number of internet users in Indonesia 38 million more. This makes Indonesia rank $13^{\text {th }}$ in the world. However, in terms of the penetration of internet users from the population of Indonesia itself based on data percentage of Individual Using the Internet, it only reached $15.4 \%$. This makes Indonesia rank $154^{\text {th }}$ in the world based on the internet user population in the country.

The development of new media in the field of internet is so fast and widespread to reach the realm of pesantren boarding schools, but the expansion of this new media does not necessarily mean being easily adopted by some boarding school institutions. There are still differences in the treatment of internet innovation adopted by some boarding schools. Some boarding schools still consider this new media dangerous and it is also considered to have a bad impact on the santri internet users. This is due to the fact that any information and data can be accessed very easily from the Internet. The above problems are just as early premise of the many problems of the Internet use in pesantren. A trial is necessary so that it can be used as a benchmark among pesantren in the use and application of internet technology although this innovation is not too new for some outside the boarding school.

The uniqueness of the characters in the handling of such issues and the differences in the adoption of this new media raises the curiosity of the authors to find out the process of how pesantren adopt the new media, and how the action of santri's communication on the use of new media internet is related to their political participation.

\section{Literature Review}

The development of today's communication technology raises the information society or the interactive communication era. The era of interactive communication was marked by the first computer findings in 1946 in Philadelphia. This era of interactive communication is also called "new media era". The new communications media include microcomputers, teleconferencing, teletext, videotext, interactive cable television, and communications satellites(6). Internet as a form of new media has a very advanced leap compared to another mass media. In this case, the Internet can be defined as a large worldwide computer network which connects computer users from one country to another throughout the world and there are various information resources ranging from static to dynamic and interactive(7).
The development of the Internet has influenced social life on many levels. The existence of the Internet has not only created a fundamental social change, but also has led to the extreme conditions of "death of the social". Apart from this extreme thinking, Yasraf (8) said that the influence of the Internet on social life is at least can be seen on three levels, i.e. individuals, interpersonal, and communities.

In addition, the changes caused by the use of technology in many cases will influence the human experience and perception. Human perceptions of the world-life will change when technology becomes a medium between humans and the world-life. Direct perception of human without technology is different from human perception when he uses the instrument, because the perception is mediated by the instrument itself. Furthermore, Don Ihde (9) explains: "Not only have our perceptions changed - those embodied through instrumentation are incommensurate with naked observation in however small degrees it is- but so also have our praxes". Thus, the way of human beings use technological tools automatically changes his relation to the life-world compared to when they do not use technology tools.

The relationship of human-technology tools-world has existential characteristics. Phenomenologically, three types of relationships can be described in which the tools influence the way humans experience the world-life, namely: 1) Internet technology changes the perception of time, 2) Internet technology changes spatial perception, 3) Internet technology changes language perception. At the beginning, history of the internet is identical with education (research). But in the context of Indonesia, the Internet is synonymous with business and entertainment. So, the Internet as a technology can be used according to the interests of its users. This was confirmed by Onno W. Purbo (in Ruhiyat, 2005), an Information and Communications Technology (ICT) practitioner, in his notes during the World Summit on Information Society (WSIS) 2003 in Geneva. There is no country in the world, except Indonesia, which has a history of more than 10 years of building its information society without government support. This form of disappointment does have adequate reasons because it is proven that the private party has an important role in introducing information and communication technology (ICT) in Indonesia. One of the spearheads in the introduction of the Internet to the public is the presence of the Internet cafes (Warnet) which although its business is still perceived by the public as a mere entertainment business.

In the study of Said Romadlan(10), a study on "Diffusion of communication technology innovation (the internet) among $\mathrm{Mu}-$ hammadiyah pesantrens", the approach is qualitative descriptive, with the grounded method in reflection and openness. The study makes the stages of diffusion of communication technology innovation (internet) in pondok pesantren Karangasem Muhammadiyah include two stages of the initiation and implementation phases. The initiation stage includes a process called agenda setting or the determination of the need for internet and matching; adjustments before internet adoption takes place. While the implementation stage includes the process of redefining or restructuring, the process of internet implementation in boarding school which is used as a means of supporting learning media and the needs fulfillment of the students through the internet cafe. The next process is clarifying and routinizing; it is when the Internet has been used in daily activities in the boarding school environment for the students, and when the Internet is used for looking for teaching materials for the teachers. At this stage the internet has really become an integral element of boarding school. Related to its implementation, the internet is applied into three areas. First, it is in the foundation offices where hotspots are used as a facility for foundation managers and the teacher. Second, it is in the computer laboratory of each school as a media or place of learning for students. Third, it is in the internet cafe that functions as a facility to meet the students' needs of the Internet. The factors that influence the adoption of the Internet is first, because the Internet as a form of an innovation is very useful and provides many advantages for boarding schools; second, because the compatibility between the Internet as a form of innovation with the values or norms adopted by 
this boarding school institution; and third, because the view that the internet is a worldly problem which business is left entirely to each other.

Siti Munawwarah (11) also conducted a study about Internet and Student entitled Phenomenology Study of Internet Usage as media Development of student's knowledge and insight at Pesantren Islam At Tauhid Sidoresmo Surabaya. The method used is descriptive qualitative method with critical analysis. The theory used in the study is Uses and Gratification. The results showed that the use of the Internet in Pesantren Islam At Tauhid still lack awareness from the students. This is due to the lack of Internet facilities, which cannot accommodate students who want to use or learn the Internet; and the students who use the internet only focused on religious issues. This causes saturation on the students in using the Internet; and also limited time was given to the students in using the Internet, which is only at the time of the internet lesson.

The behavior of internet utilization is also used as the theme of study by Weny Rochmawati (12) with descriptive study on Internet Utilization for Entertainment and Academic Interest on Children in Surabaya. Her study explains that when children decide to get to know the internet and join social networking sites or for the sake of looking for information, children must have the same wishes with their playmates.

Internet use by the children prefers to open websites or website addresses related to fun or leisure interests. They do not prioritize the interests associated with their academic activities at school. This is in accordance with the theories of use and gratification, where there are several reasons for fulfillment of someone who wants to be fulfilled in using the media. One of them is because the need for social integration, which is a need related with the addition of family, friends and the outside world contacts. These things are based on a desire for affiliation. With the support of adequate information technology tools and access to an almost unlimited internet network, those who are already internet-savvy can easily get entertainment and the most up to date news in seconds.

There is a study of pesantren conducted by Baskoro Adi Nugroho(13), which is about the social relationship of Kyai with santri mukim (those who live in the boarding schools) and santri kalong (those who live in their own houses) at Al Muthi'in boarding school in Maguwo, Bangun Tapan, Bantul, Yogyakarta. The pattern of social relationship of Kyai with santri mukim and santri kalong in boarding school can be explained in three patterns or models: cooperation, competition, and contradiction. There are differences in how Kyai has a relationship with santri. Kyai has a more effective relationship with santri mukim because cooperation, competition, and opposition based on social contacts and communication factors work well. In contrast, the social relationship of Kyai with santri kalong only runs on the issue of cooperation alone.

Zainuddin Syarif (14) in his study of Political Dynamics of Kyai and Santri in Pilkada Pamekasan explains that the emphasis on the interpretation and analysis of emic meaning in the form of phrases (empirical) found in the field. The theoretical perspectives used are elite, conflict, and prismatic theory. Methods of data collection used include observation, in-depth interview and documentation. This study used an unstructured inclusive interview. First, the Kyai's political formula used in maintaining its leadership authority over the santri rests on two forces: traditional and charismatic domination. It means that Kyai is still retaining the charm as a religious charismatic figure through the symbols of obedience that frame the moral values of religion in maintaining adherence of his santri. Kyai can give barakah when they follow him. And Kyai can bring ugliness if they dare to be different from him, by using symbolic expressions, tawadu, muru'ah, tola and bhasto. Second, political behavior of santri has been a shift from political obedience to political differences even though it is done by the santri alumni. Based on the santri's political behavior above, three political typologies of santri were found: (1) the absolutely obedient students, (2) obedient students and (3) prismatic students.
Arief Munandar (15) conducted a study entitled Between Jemaah and Political Parties: Habitus Dynamics of Cadres of Partai Keadilan Sejahtera in Indonesian Political Arena Pasca-2004 Election. Qualitative approach with case of study is used in his study. It tried to provide descriptions and deep explanations about internal dynamics of PKS in the Indonesian political sphere. The study of political parties has also been done by Firdaus (16) entitled Communication of elite political Nahdlatul Ulama Pasca New Order. The approach is ethnomethodology. Qualitative method includes observation and deep interview, data collection, verification and confirmation (crosscheck), emic perspective based on the assumption/analysis of the subject matter with the reality. Emphasis is on the changes of elite political communication.

Irianto (17) also investigated voter political behavior in the election of East Java governor period 2008-2013. The approach used in this research is explorative with qualitative approach aimed to identify voter preferences of East Java governor candidate period 2008-2013. The result shows that voter preference is more due to the similarity of regional origin, religion, gender equality especially in arek culture, the son of the area either on the culture of Mataraman, the culture of Pendalungan and arek culture, the experience of leading the organization, the educational status has high economic status, professionals, intellectuals, interesting campaign issues, candidate's vision and mission, candidate's credibility, and a clear work program. Factors influencing voters' political behavior during 2008-2013 periods include religion, friends, political advertisement, and elder people. The source of information about PILGUB was mostly on the mass media television.

\section{Methodology/Materials}

The interpretative or qualitative paradigm being the approach in this research study is based on the subject's interpretation, and the research findings are context-bound. Qualitative research is a study that describes a problem that the results can be generalized(18). Qualitative research (paradigmatic) study also assumes that the behaviors and meanings of a group of people can only be understood through an analysis of their natural setting(19). The use of the method is by using ethnographic methods in which research on the way of life of society(20). Ethnographic research requires researchers to immerse themselves in the lives of the subjects studied(21). The field study is with very detailed descriptions from an insider's point of view(22). Ethnographic research demands an interpretation behind meaning and motivation(23), proximity to background or social situations and elaborated analysis, detailed description, and interpenetration of data concepts (Lofland, 1996, In Berg 2001). Goetz and LeCompte (1984, in O'Donoghue, 2007) illustrate the ethnographic goal by providing rich descriptive data about participants' context, activities, and beliefs.

As Creswell puts it (in Engkus, 2008), there are three main techniques of data collection in ethnographic studies: observer participants, interviews, and document review. This data collection method is used generally in this study.

\subsection{Sample and Location}

This study involved several caregiver boards and several Banyuanyar students who have been recruited to use the Internet in the boarding school and stepping on the age of 17 years old and above, the age that has been allowed to engage in elections (Pemilu) and election of regional head (PILKADA). 

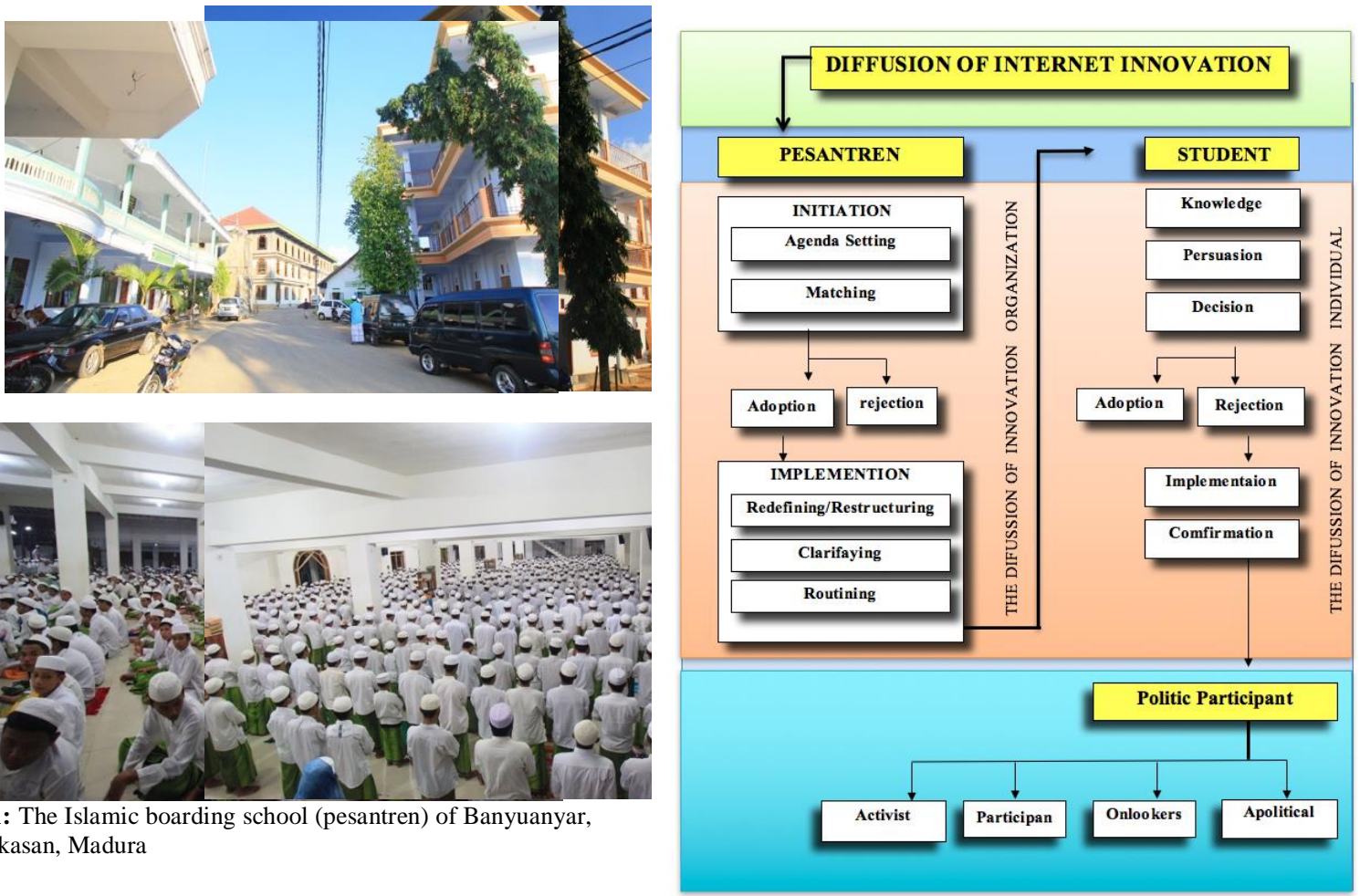

The location of the study is in Pesantren Banyunyar which was established by Kyai Isbat located in Pamekasan district, precisely in Potoan Daya area, Palengaan, Pamekasan, East Java. The area of land occupied by the pesantren is around 17 hectares. This pesantren is considered old because it was estimated to be established in $1204 \mathrm{H} / 1788 \mathrm{M}$. The fifth generation of caretaker in Banyuanyar pesantren now is K.H. Muhammad Syamsul Arifin. Based on data pesantren that has been recorded in the year 20072013, Pesantren Banyuanyar has santri of approximately 5251 male students who settled in the boarding school. This does not include female students who also have reached thousands. The number of students does not include students who do not live in lodges; they are the students from surrounding communities who take the education program at boarding schools, but do not settle in the boarding school.

\subsection{Theory}

Some theoretical combinations undertaken for this study include the innovation diffusion theory developed by Evert M. Rogers (6) that divides the diffusion of innovation into two parts; they are the diffusion of organizational innovation and the diffusion of individual innovation. And the theory of political participation by David F. Roth and Frank L. Wilson(24) structured political participation into the pyramid of participation. The process of studying the diffusion of innovation and political participation will be used in analyzing the study to answer: first, about how the process of diffusion of internet innovation and its application in boarding school; second, about how the behavior identification (communication action) of santri is through new media in boarding school and third, about how new media and santri relate to political participation in Madura. The conceptual framework scheme in this

Fig. 2: Diffusion of Innovation Model by Evert M. Rogers (6) adapted with political theory of David F. Roth and Frank L. Wilson (24)

The diffusion of new Internet media innovations will begin from the process of organizational innovation diffusion through boarding schools. The policy of internet adoption departs from the policy provided by the boarding school institution for the santri, where students in using the Internet in boarding schools must use according to existing boarding rules. Furthermore, the adoption made by individual students reach the new media relations and political participation in using the Internet in the boarding school.

\section{Results and Findings}

The study of fostering santri's political participation through the diffusion of new media innovations in Madura will be divided into three sections, first: the findings of the study that will begin with the diffusion of new media innovations organizationally (pesantren institutions). The existence of Internet innovation as a new media and socialization efforts, how the efforts of Pesantren receive, apply and use it for the benefit of pesantren. Secondly, regarding the individual diffusion of innovation (santri) from pesantren applies internet usage, to be studied how they do communication action of internet in pesantren. Third, the study of internet usage in pesantren and the actions that is taken related with the fostering of political participation. Some efforts from various sources that can be found to support result of the study, both from the results of interviews, documents as evidence, and the attention to santri in using internet media in boarding schools. 


\subsection{Adoption of Internet Media in Pesantren}

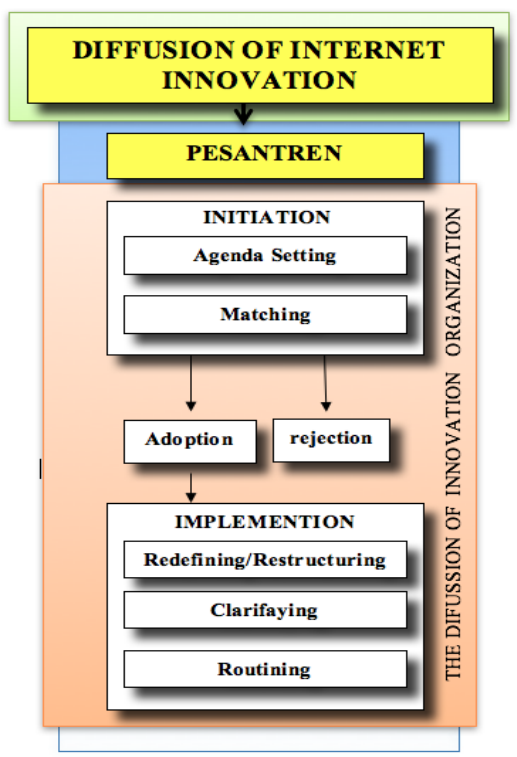

Fig. 3: Diffusion of organization innovation (6)

The existence of Pesantren Banyuanyar is classified as pesantren middle salafi modern who still prioritize non-formal education, but still accepts a formal education. Pesantren Banyuanyar is able to receive new media that is the internet as one of the media that was originally used for administrative support facilities, and furthermore the allocation was developed to be used by the santri as a means of supporting the development of education and knowledge. Pesantren Banyuanyar is aware that using the internet media would increase the cost of pesantren's budget in terms of fulfillment of internet network which is certainly not obtained for free, in addition to the budget of provision and maintenance of media devices (computers) itself. They use internet service Telkom Speedy network which is owned by PT. Telekomunikasi Indonesia Tbk (TELKOM).

The pattern of policy issued in terms of determining the use of internet media in pesantren is based on the decision of Kyai, who is also the caretaker of pesantren, after being known and understood first by the board of the pesantren. Pesantren's caretaker board is the son of Kyai pesantren which represents Kyai in determining every policy including determination of internet acceptance used in pesantren. Very often, the counselors also have roles in and attentions on the acceptance of internet media in pesantren. Pesantren Banyuanyar has given the role and also controls the process of acceptance and implementation of internet in Pesantren. This role is given because the use of the internet is still considered sensitive and vulnerable to abuse; this is because the internet media is an on-line media that does not recognize the geographical boundaries. These caretakers have a high interest and concern for the entry of internet media into pesantren, even though they do not depart based on educational backgrounds (Computers and Networks).

The socialization of internet use to the students is delivered by the computer laboratory manager based on scheduling and applicable provisions. The application of internet usage will not necessarily mean that santri can use it. This effort is done because of limited management and facilities that are still very minimal in schoolspesantren that is studied. Efforts are made in Banyuanyar by means of computer laboratories whose initial existence is placed in pesantren with the name DUBACOM and internet government assistance, Center for District Internet Service (PLIK). The management of this computer laboratory has the authority to convey to the students its existence and not the use of the internet for all circles. This is justified to all internet users with the provision that there is still additional cost in the management of daily operations.
Pesantren Banyuanyar got placement from PLIK which is as allocation placement in district Palengaan especially in Potoan Daya village. Unfortunately the existence of PLIK in Banyuanyar did not last long. It considers some operational constraints in the field. From several operational problems in the field, there are some things that can be reviewed in terms of services, hardware, software, experts and the knowledge of users of PLIK services itself.

\subsection{Adoption of Internet Media among Santri}

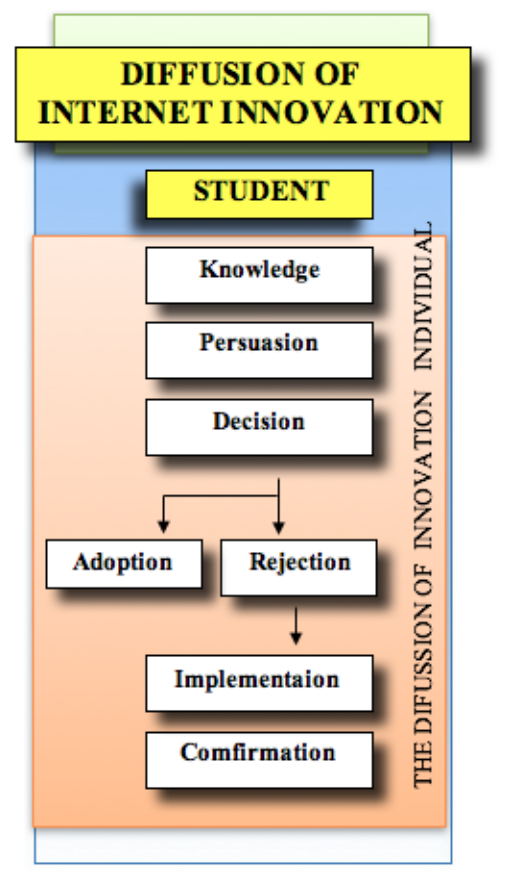

Fig. 4: Diffusion of Individual Innovation (6)

Due to restrictions on internet usage in pesantren, only certain santri can use the internet media. It is justified when students use computer facilities that have been provided by the pesantren with the applicable provisions. When it is viewed from the level of understanding of the internet itself, many school students have already had some knowledge about the Internet before they are in their pesantrens. However, when there is special enforcement for certain students who can use the internet, the restriction makes some students unable to develop further what they once knew. This is in contrast with those who already have permission to use the Internet because they either have the authority or participate in the management of pesantren, or those who have entered the education level in college.

Pesantren Banyuanyar has given leeway to use the internet because there is already a special time left and the place where they can use the internet. There are no exceptions to the santri. However, this condition did not last long in Pesantren Banyuanyar because the facilities used did not go well. Pesantren Banyuanyar has a high interest and proclivity in internet usage. Pesantren Banyuanyar though once socialized to all students who are interested in using the internet through programs held DUBACOM and PLIK, but have constraints on the supply of devices. Furthermore, networks are always problematic especially when the internet network is disconnected since the telephone cable installation for the area of pesantren and surrounding areas is lost. The alternative they use is by using the mobile phone in each individual santri while there is no limit in the use of mobile phones or similar gadgets. In this case, santri "Special" can use smartphone or communication tool based on Android, Windows mobile, or OS that has internet facility that can be used to communicate by using social media like Facebook, Twitter, Instagram, Whatsapp and so on.

The weakness of internet usage in Pesantren Banyuanyar is the lack of binding and written regulations and the provision of sanc- 
tions for violators of the rules is not strict either. Internet use policy puts forward the sense of "should know yourself" and "understanding each other". It means that as a result of the limitations set by pesantren (organization) in internet use that are basically accepted and applicable with certain limitations, some rule has been violated by santri on the use of media innovation itself, such as smartphones, gadgets, mobile phones in some pesantren.

It could be argued that the effect of organizational innovation adoption may influence the recharge of individual innovations in the implementation stage. Sometimes the stage of the implementation of Internet media innovation on the individual level is forced to collide with the stage of prairie that is in the level of the organization. This means that the implementation adoption of innovation by students can be limited by the limits given by the organization namely pesantren regulation. Thus, it is not uncommon for individual adoption to violate organizational recharge limits due to the strong interest in implementing the use of such innovations, which is in this case the Internet.

The violation on the use of Internet-connected gadgets and the leniency toward the use of gadgets or mobile phones at pesantren Banyuanyar allow the possibility of violations outside the control of pesantren. The point is that there are still weaknesses of control in some pesantren against the use of communication media in relation to the problem of network content. There is an urgent need for a clear regulation on the use of communication media and information in pesantren. However, an essence should not be violated by the santri due to security in the control system to the santri.

\subsection{Political Participation of Santri}

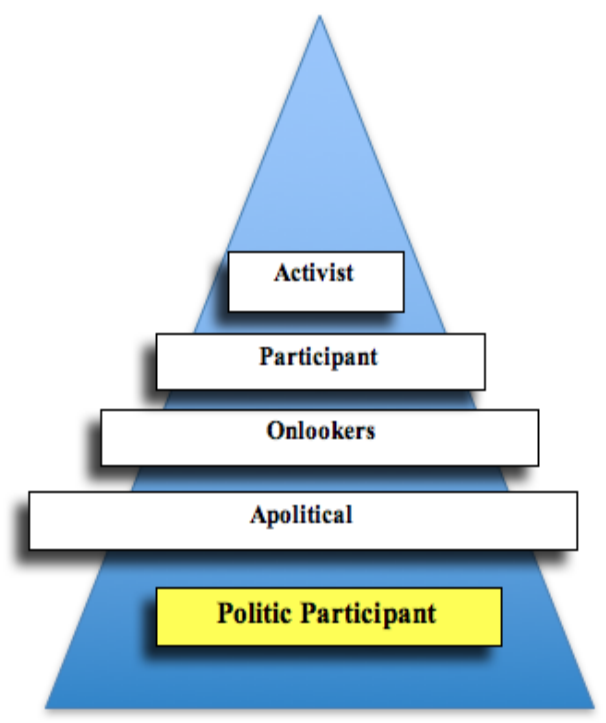

Fig. 5: Pyramid of Political Participation (David \& Frank, in Budiarjo, 2012)

In principle, all Indonesian citizens have the same freedom and rights as Indonesian citizens including the relation with the right to vote or to be voted in a political choice. Its meaning includes also the santri wherever they are located, including the santri of Banyuanyar.

The power network owned by the Kyai can be mapped that Kyai as the supreme leader who governs and directs Pesantren along with all its policies, is helped by Kyai's relatives who are often referred to as Dewan Pengasuh Pesantren (board caretaker). Then the policy is forwarded by the Ustaz and management who are fully responsible to the Kyai who acts as a head of the organization and administration of pesantren. While santri themselves are fully responsible to the Kyai and ustaz as executors in the field. And not infrequently also forwarded by the alumni who serve as a liaison between society and Pesantren.

This is reflected in the study obtained from the field data in a study of political participation by students. Banyuanyar's santri is open in terms of interests and political choices because the caretaker of the pesantren itself is also one of the members of the Majelis Syariah DPP Partai Persatuan Pembangunan (PPP) at the central level. Moreover, some alumni are also involved in party affairs. Party talks are not taboo among them. Very often, there are santri who participate as a political participant.

The socialization of the political network from Kyai level to the santri level has influenced the high level of knowledge about the politics of the students of Banyuanyar who have loosened their santri to study and interpret politics according to their understanding and perception. It can be seen in the political background of the leaders and caretakers of the pesantren who have been affiliated with one of the Islamic political parties, the Partai Persatuan Pembangunan (PPP) as a political vehicle. But it does not mean that the pesantren policy requires choosing the party as chosen by the caretakers, because it deals only with the ideology of the party, not practically related to religion. The values of democracy in Pesantren Banyuanyar also take place. There is no authority that forces to choose according to the choice of caretakers and their leaders. The result of the head of regional election (Pilkada) in Pamekasan showed that there were santri who voted outside the general policy of Pesantren Banyuanyar. It means that it does not have to be the same attitude as the politics of the Kyai.

\subsection{Founding of Political Participation through Internet Media}

The use of electronic media, especially the internet, has provided a great opportunity to absorb some information from outside. Much of the information coming through the Internet window provided new discourse in various activities, including political activities. Political activism is limited to get information politics in the country and abroad, as well as participates in cyber war in political affairs. It is possible that the user will lurk and infiltrate the opponent just reading on the power map, or reading the map of the strength and direction of the opponent's political objectives with surveillance via social media and some internet-related networks. It would be very interesting if the free and unrestrained internet sphere is used by santri who find it difficult to use reconnaissance as well as an opinion fragment to the wider community to equalize the vision according to the choice and political affiliation of the internet user. Difficulties arise due to their presence in pesantren where there are some rules that must be obeyed and bound; they are not permitted to go out of pesantren without having permission from the officers or the board.

Santri Banyuanyar is open to political talks. As if being an ordinary and commonplace to talk about among them, especially in social media content on the internet. As if there is no doubt and a concern to declare and give political-related phrases/reviews. Instead, they feel that they are talking about political issues even what are affiliated with the guardian's political choices, the more courageous to reveal. Occasionally they also disclose, at least an answer or just give "like" to the account that responds positively. The use of the Internet as the delivery for political aspirations of the santri is one alternative that can be used when they are not allowed to go out of pesantren. The Internet is the most strategic liaison for santri to the outside world. Many alternatives can be offered by the internet. Even good information or bad information, all through the same channel, it is the internet. It just about how santri use it. Control is by other than the internet provider in pesantren. It is also by colleagues themselves if there is information or access portal that is considered not good, especially until things have been considered prohibited by pesantren. Other santri also do monitoring if there are violations committed.

\section{Conclusion}

In general, Pesantren Banyuanyar in principle accepts the existence of internet media, but has a shortage of handling of computer equipment (Hardware), Application Program (Software) especially 
lack of experts plus there is a lack of knowledge of service users to the facilities provided.

For the santri, the trend towards the internet is very accepting, even most santri have understood the internet knowledge before they come into pesantren. Even the limitations of media facilities do not rule out violations of the rules of pesantren just for the fulfillment of internet use in pesantren, especially in the use of media tools in addition to possible violations of communication through social media.

Efforts are made to identify deviations in ethics regarding the manner of communication conducted by santri in the use of new internet media. The identification of the Internet provides freedom space, but on the other, the pesantren does not have virtual security officers to deal with digital violations that may be committed by the students. The early identification of an effort is necessary to anticipate the adoption of innovations and to make boarding school students media-intelligent.

The adoption of innovation in pesantren (organization) can influence the adoption of innovation of santri (individual) in its implementation stage. At the stage of implementation, however, Internet media innovation on the individual level is limited to the stage existing in the level of the organization.

Banyuanyar students also have the tendency to participate in political activities although they are not fully involved in it due to limited space in the pesantren. The development of political participation for the santri using electronic media has an indirect but significant contribution to educating the mindset of the society in general and the santri community in particular. It is expected that there will be behavioral changes especially among the santri in their social perspectives on dynamism in the fulfillment of human rights and democracy.

\subsection{Implication of Study to Pesantren}

A study of Internet media adoption in pesantren is expected to provide implications for handling the use of internet media in pesantren. In addition, the use of internet media is not only a means of support for the purposes of administrative facilities in pesantren but also helps to blow up information from pesantren to some institutions outside it particularly for people who need information about the pesantren.

The provision of internet media facilities in pesantren must also consider the appropriate tools for the benefits of pesantren, considering the fact that the facilities provided are not cheap devices. Besides, the pesantren budget policy also needs to consider the fulfillment of tools necessary for the purpose. Strict rules related to the use of the Internet in pesantren are also required in order that the Internet facilities will not be used for immoral and criminal acts as well as any activities that can damage the ideology or confidence.

\subsection{Implication of Study to Students}

The study of adoption of innovation in new internet media among students is expected to imply the use of the internet in a healthy manner. This means that the basic scholarship that has been obtained in pesantren becomes the value of control over the flood of information provided by the internet media. Therefore, the internet users can really get the benefits from using the Internet and it is particularly to get important and relevant sources of information. This is because the purpose of internet presence in boarding schools is to meet the needs of teaching and learning processes, especially to get more information and knowledge.

\subsection{Implications of study to Government Policy in Ma- dura}

Expectations that can be given to policy makers, especially in Madura, are more concerned about data and telecommunication services. Very often certain areas lack the proper information caused by the absence of internet services in the countryside. If the community has adequate media facilities, the community creates study groups as well as associations related to community-related fields and professions so that information services for the community can spread widely. This can include the handling of center for District Internet Service (PLIK) which still has a lot of obstacles in the field partly because of the lack of control and development of the services provided. The provision of assistance is also often right on target, so the programs provided by the government do not run normally and tend to stop, and then die.

\section{References}

[1] Direktori Pondok Pesantren di Indonesia. pendiskemenaggoid [Internet]. 2008. Available from: http://pendis.kemenag.go.id/index.php?a=artikel\&id2=statponpes 20 09\#.VM_bv3Z4hFU.

[2] Nasution Z. Komunikasi Pembangunan Pengenalan Teori dan Penerapannya. Jakarta: Rajawali; 2002.

[3] Meeker M. Indonesia, Pengguna Internet Nomor 3 Dunia. wwwtempocom 2012

[4] Indonesia Peringkat Kelima Pengguna Internet di Asia. wwwrepublikacoid2008.

[5] Key ICT indicators for developed and developing countries and the world (totals and penetration rates). wwwituint [Internet]. 2012. Available from: http://www.itu.int/en/ITUD/Statistics/Documents/statistics/2012/ITU_Key_20062013_ICT_data.xls.

[6] Rogers EM. Communication Technology the New Media In Society. New York: The Free Press; 1986.

[7] Triharja. Kamus Istilah Internet. wwwbogorindosatnetid [Internet]. 2000. Available from: www.bogor.indosat.net.id/ja3.

[8] Piliang YA. Cyberspace dan Perubahan Sosial: Eksistensi, Identitas, dan Makna. Jurnal Balairung. 2005;38.

[9] Lim F. Filsafat Teknologi: Don Ihde tentang Dunia, Manusia dan Alat. Yogyakarta: Kanisius; 2008.

[10] Ramadlan S. Difusi Inovasi Teknologi Komunikasi (Internet) di Kalangan Pondok Pesantren Muhammadiyah. lemlituhamkaacid [Internet]. 2012. Available from: http://lemlit.uhamka.ac.id/files/difusi-teknologi-internet.pdf

[11] Munawwarah S. Internet dan Santri: Studi Fenomenologi Penggunaan Internet sebagai media Pengembangan pengetahuan dan wawasan santri di pondok pesantren islam at Tauhid Sidoresmo Surabaya. Surabaya: IAIN Sunan Ampel; 2009.

[12] Rochmawati W. Perilaku pemanfaatan internet (studi deskriptif tentang pemanfaatan Internet Untuk Kepentingan Hiburan dan Akademik di Kalangan Anak-Anak di Kota Surabaya. Surabaya: UNAIR; 2006

[13] Nugroho BA. Hubungan Sosial kyai dengan Santri Mukim dan Santri Kalong di Pondok Pesantren Al Muthi'in Maguwo Banguntapan Bantul Yogyakarta. Yogyakarta: UIN Sunan Kalijaga; 2010.

[14] Syarif Z. Dinamika Politik Kiai dan Santri dalam PILKADA Pamekasan. Surabaya: IAIN Sunan Ampel; 2010.

[15] Munandar A. Antara Jemaah dan Partai politik: Dinamika Habitus Kader Partai Keadilan Sejahtera dalam Arena Politik Indonesia Pasca Pemilu 2004. Jakarta: Universitas Indonesia; 2011.

[16] Firdaus. Komunikasi Politik Elit Nahdlatul Ulama Pasca Orde Baru. Jakarta: UIS Syarif Hidayatullah; 2008.

[17] Irianto. Perilaku Politik Pemilih Pada Pemilihan Gubernur Jawa Timur Periode 2008-2013. Jurnal Penelitian Komunikasi. 2007.

[18] Kriyantono R. Teknik Praktis Riset Komunikasi. Jakarta:: Kencana; 2006.

[19] Mulyana D. Metodologi Penelitian Kualitatif: Paradigma Baru Ilmu Komunikasi dan Ilmu Sosial Lainnya. Bandung: PT. Remaja Rosdakarya; 2008

[20] Daymon, Christine, Holloway I. Qualitative Research Methods in Public Relations and Marketing Communications. New York: Routledge; 2005.

[21] Denzin NK, Lincoln YS. Handbook of Qualitative Research. Yogyakarta: Pustaka Pelajar; 2009.

[22] Neuman WL. Social Research Methods: Qualitative and Quantitative Approaches. Jakarta: PT. Indeks; 2013.

[23] Savin B, Maggi, Major, Howell C. New Approaches to Qualitative Research: Wisdom and Uncertainty. New York Routledge; 2010.

[24] Budiarjo. Partisipasi Politik. Jakarta: PT. Gramedia; 1998. 